\title{
Identifying the Factors of a Happy Worker: Case of Private Banks of Bangladesh
}

\author{
Zerin Tasnim*, Afreen Ahmad Hasnain \\ Lecturer, School of Business Studies, Southeast University, Dhaka, BANGLADESH \\ *Corresponding Contact: \\ Email: zerin_tasnim91@yahoo.com \\ Cell Phone: +8801713178443
}

\begin{abstract}
A happy worker at workplace has a direct impact on the overall quality of his/her life and therefore it's very important to understand what makes us happy or unhappy at work. Also a happy worker is an important factor for all organizations development and to enhance its productivity. A company should focus on workers to be happy because of their own improvement. But, surprisingly, there is an absence of sound framework for understanding such an important issue from both workers' and organization's perspective.

This study focus on various kinds of workplaces of Bangladesh and for this purpose a survey is done among 200 employees of six private banks within both male and female employees. The present study focuses on five particular phenomena related to identify the dimensions of a happy worker as psychological wellbeing, peer behavior, work family conciliation, work stress, management cooperation and personal development.
\end{abstract}

Key Words: Happiness, Bangladesh, Psychological wellbeing, work-family conciliation, peer behavior

\section{INTRODUCTION}

The search for happiness is perhaps as old as human history. On the global stage, it's clearly proved that the psychological and philosophical study of happiness began in China, India and Greece more than 2,500 years ago. Again in today's world, there is a vast interest regarding happiness. As much of the waking life of modern human beings are spent in some kind of work setting- how happy we feel at work has a direct influence on the overall quality of life as well and , therefore, understanding what makes us happy or unhappy at work and why is so important. In this paper, we combine the theoretical and empirical research and try to find out the factors that affect a happy worker .By studying these factors; an organization will get the opportunity to identify the factors that are associated with the happy worker. By understanding the employees' happiness, their demands and requirements, an organization can easily maintain their workers' happiness and the consequence is worker's motivation and loyalty that can ultimately beneficial for organizations. 


\section{ObJectives}

The study is conducted to explore the factors of happy worker in private banks of Dhaka City. The study is an exploratory research to determine the factors related to happy worker. The research also sheds light into the following facets of happiness at workplace:

\section{LITERATURE REVIEW}

According to Danna and Griffin (1999), some researchers identify mental and emotional issues are somewhat separate from organizational issues. Research by Towers Perrin (Reported in WORKLIFE 2003) viewed that there is still a massive gap between workers' current and ideal work experience and there is plenty of space for improvement in Quality of work life (QWL) from the individual worker's perspective.

The congruence model of Subjective Well Being (Kafka \& Kozma, 2001) has shown, a worker is happy when there is similarity between this mental model and the external environment.

Organizations are social units and examining issues of happiness within the workplace is not a new idea (Cheney, 1995).Yet, it remains one of the least understood organizational phenomena (Rowden 2002). This may occur because, within the framework of OB and HRM, happiness with work (a somewhat narrower scope than happiness) is a fairly recent concept and has evolved from the works of management thinkers like Mary Parker Follet, Chester Barnard and, Elton Mayo and their work was defined by their ideas on human relations.

Mckenna (1999) provided a historical overview of modern management which showed those who followed like Mcgregor, Likert, Argyris, Hertzberg- while expanding on Maslow's ideas, offered no further advances with respect to need satisfaction concepts. Rather, later on, concepts such as 'happy worker' had mostly been relegated by management scholars in favor of economic maximization approach. But, if we look deeper into organizational behavior, the happiness of workers' is the fuel that moves humankind, which makes workers', motivated to perform all activities including in organizations.

The environmental mismatch theory formulated along this line and it identified that the stress within the person create a gap between the value system and the work demands (Bailey, 1997; Janicki \& Krebbs, 1998). In minor instances, the individual is able to cope and reduce stress, through mechanisms such as cognitive dissonance, adaptation and manage the mismatch (Stone \& Cooper 2000; Hogg et al. 1995). But when there is an unbridgeable gap between the personal and organizational values and needs, the attempt at reduction becomes less effective, and that leads to stress in individuals both in family life and in organization in major instances.

Happiness at workplace is less explored. Researches more are inclined towards finding unhappiness facet like depression, anxiety, stress, and emotional disorders. However, Furnham and Crictoforou (2007) termed well-being as a synonym for happiness and more research are being conducted on this topic. Research suggest that employees who are not happy as oppose to a happy employees, they are more willing to help co-workers and customers, have better performance, and able to do more work itself and has a high devotion towards the organization.

According to research conducted by Tom Wright of the University of Nevada and Russell Cropanzano from the University of Arizona that happy employee showed superior performance and they are more responsive to the opportunities in the workplace, more open and help co-workers, and more optimistic and confident. According to Tseng (2009), 
efficiency can be gained by happy workers' attitude towards organization to achieve organizations goal. To attain a high performing organization, manager must take into account of poor morale, low productivity, and strikes.

\section{Methodology}

Data is collected from a sample of 200 employees of six private banks of Bangladesh based in Dhaka.. All are university graduates and have wide range of job working in various positions in their respective banks. The data were collected using closed -ended questionnaires comprising of 23 questions. A five point Likert scale (1=strongly disagree, $2=$ somewhat disagree, $3=$ disagree, $4=$ somewhat agree, $5=$ agree). The time frame of the data collection was a month starting from February 2016 to March 2016.

After reviewing literature 22 questions were developed into five sub-dimensions namely psychological wellbeing, peer behavior, work family conciliation, work stress, management cooperation, and personal development. In Table I of the appendices the five dimensions and their respective questions for each dimension are mentioned.

Various statistical methods were used in this research paper to analyze the data collected from 200 respondents and the statistical software SPSS 21.0 was used.

All statistical analysis was conducted using SPSS 21.0. Firstly, frequency tables and descriptive statistics were calculated to provide an overview on results for each twenty three items. Then a reliability test was conducted. Reliability with the Cronbach's Alpha test was used to estimate the internal consistency reliability by determining how all of the variables are related each other. The Alpha value was set at .7 as established by Spector (1997:32). The survey sample respondents were 200 as required for an item analysis (Spector, 1997:29). Factor analysis was conducted to determine the items would load heavily on the factors and load poorly on other factors. Factor Analysis is a multivariate statistical technique used to reduce and summarize all inter-dependency of variables. Dependency between one variable and another one will be tested for the identified dimensions or factors (Maholtra,1996).According to Comrey (1992) factor loading coefficient .71 or higher is excellent; .63 to .70 is very good,.45 to .54 is fair and .30 to .44 is poor was established. Factor loading coefficient represents the strength of the association or items with the factor.

\section{FINDING AND ANALYSIS}

The findings of data focus on the measures of central tendency to consider where in the distribution the value falls. For each of the dimensions mean and standard deviation is calculated.

Among the 200 respondents, $68 \%$ were male, and 32\% female and all of them were working full time with an average work experience of 5.4 years. All the respondents suggested that this was their first job.

\section{Descriptive Statistics}

The Table I shows the results of the dimension "psychological wellbeing" which has factor five items (variables): The mean score of the five factors are 4.24, 4.54, 4.48, 4.39 and 3.79 respectively, implying that all respondents agreed with the factors. However in terms of job security respondents disagreed showing a less favorable opinion with a mean score of 3.79.

Table I. Descriptive statistics of dimension psychological wellbeing 


\begin{tabular}{|l|l|l|}
\hline Question(s) & Mean & Standard Deviation \\
\hline 1. I am happy with my efficiency of work & 4.24 & .891 \\
\hline $\begin{array}{l}\text { 2. My supervisor believes that I can fulfill my } \\
\text { responsibility efficiently. }\end{array}$ & 4.54 & .633 \\
\hline $\begin{array}{l}\text { 3. My peers believe that I'm confident and productive } \\
\text { employee }\end{array}$ & 4.48 & .722 \\
\hline 4. I am valued by my supervisor & 4.39 & .801 \\
\hline 5. I've strong job security in this. & 3.79 & 1.230 \\
\hline
\end{tabular}

The Table II below shows the results of dimension "interaction with peers and coworkers" which consist three variables: The mean for all the three factors are 4.28, 4.26 and 4.16 respectively signifying that the respondents "somewhat agreed" with the factor. Therefore the respondents are having a positive regarding interaction with their peers and coworkers. The standard deviations for three factors are $.826, .997$ and .833

Table II. Descriptive statistics of dimension interaction coworkers and peers

\begin{tabular}{|l|l|l|}
\hline Question(s) & Mean & Standard Deviation \\
\hline 6. My colleagues behave positively in my achievement & 4.28 & .826 \\
\hline 7. My colleagues help me to solve work-related problems. & 4.26 & .997 \\
\hline $\begin{array}{l}\text { 8. I receive adequate opportunity to interact with other } \\
\text { employees on a formal level. }\end{array}$ & 4.16 & .833 \\
\hline
\end{tabular}

Table III provides the results of the dimension "work family conciliation" which consist of seven variables. For the first three factors the mean score is between 3.23 and 3.89 which states that the respondents are not affected by the factors mentioned and are disagreeing with statements. The standard deviation is $1.17,1.101$ and 1.509 respectively which suggests that the deviation from the mean score is high. For the seventh factor, the mean is 3.45 shows that respondents feel they are able to balance between their work and other aspects of life.

Table III. Descriptive statistics of dimension work family conciliation

\begin{tabular}{|l|l|l|}
\hline Question(s) & Mean & Standard Deviation \\
\hline 9. The distance between my workplace and residence long & 3.89 & 1.178 \\
\hline $\begin{array}{l}\text { 10. Due to my work pressure i feel mentally pressurized } \\
\text { and it affect my family life }\end{array}$ & 3.74 & 1.101 \\
\hline $\begin{array}{l}\text { 11. Regularly I get late to reach home after work as } \\
\text { workload is so high that it takes two to three hour more } \\
\text { at office after regular time. }\end{array}$ & 3.23 & 1.509 \\
\hline $\begin{array}{l}\text { 12. Problems associated with my job kept me awake at } \\
\text { night. }\end{array}$ & 2.93 & 1.339 \\
\hline $\begin{array}{l}\text { 13. The company has a positive image to my friends and } \\
\text { family }\end{array}$ & 4.27 & .901 \\
\hline $\begin{array}{l}\text { 14. The company is flexible with respect to your family } \\
\text { responsibilities }\end{array}$ & 4.16 & .946 \\
\hline $\begin{array}{l}\text { 15. You are satisfied with... the balance between the time } \\
\text { you spend on your work and the time you spend on } \\
\text { other aspects of your life }\end{array}$ & 3.45 & 1.235 \\
\hline
\end{tabular}

Table IV below depicts the descriptive finding of the dimension "work stress" which consists of three variables. The mean score ranges from 3.81 to 4.20 . The mean score 4.20 or whether they work under lots of pressure suggests that the respondents somewhat agree to this 
situation suggesting that there are work pressure. However the mean of 3.83 and 3.81 suggest that majority of the respondents have positive feeling regarding fairness treatment and open discussion with management.

Table IV. Descriptive statistics of dimension work stress

\begin{tabular}{|l|l|l|}
\hline Question(s) & Mean & Standard Deviation \\
\hline 16. I work under a lot of pressure & 4.20 & .939 \\
\hline $\begin{array}{l}\text { 17. I'm facing lack of open and frank discussion with } \\
\text { management. }\end{array}$ & 3.83 & .925 \\
\hline 18. I feel lack of equity or fairness & 3.81 & .949 \\
\hline
\end{tabular}

The Table V below shows the result of descriptive statistics of dimension "personal growth" which consists of four items. The mean value ranges from 3 to 3.91. This indicates that respondents feel in their workplace there is very little opportunity to show creativity while there is opportunity for personal growth.

Table V. Descriptive statistics of dimension personal growth

\begin{tabular}{|l|l|l|}
\hline Question(s) & Mean & Standard Deviation \\
\hline $\begin{array}{l}\text { 19. I get enough opportunity of personal growth such as } \\
\text { updating skills and learning different jobs in my work. }\end{array}$ & 3.91 & 1.166 \\
\hline $\begin{array}{l}\text { 20. I get opportunity to show my imagination and } \\
\text { creativity in my work. }\end{array}$ & 3.00 & .985 \\
\hline 21. I get enough training to develop my competency. & 3.67 & 1.273 \\
\hline 22. I have a clear path for career advancement & 3.88 & 1.064 \\
\hline
\end{tabular}

Table VI below illustrates the overall factors of happy respondents at organizations. The result shows that a mean score of 2.45 and a $48.5 \%$ of total respondents suggested that they are happy with the job.

Table VI. Overall Happiness

\begin{tabular}{|l|l|l|}
\hline & Frequency & Percentage \\
\hline Very happy & 12 & 6.0 \\
\hline Happy & 97 & 48.5 \\
\hline Somewhat happy & 65 & 32.5 \\
\hline Unhappy & 24 & 12.0 \\
\hline Very unhappy & 2 & 1.0 \\
\hline Total & 200 & 100.0 \\
\hline Mean & 2.54 & \multirow{2}{*}{} \\
\cline { 1 - 2 } Median & 2.00 & \\
\cline { 1 - 2 } Standard Deviation & .820 &
\end{tabular}

\section{Factor Analysis}

In order to perform factor analysis the coefficient alpha for reliability analysis was administered. According to Janu warsono (2015, pg.14) Kaiser -Meyer Olkin (KMO) measures the sampling adequacy: "KMO is an index comparing between the correlation coefficient with the partial correlation coefficient. It will create a value close to 1 , if the sum of squared partial correlation coefficient all pairs of variables has a low value when it is compared with the sum of squared correlation coefficient. The value of KMO was sufficient if more than 0.5."In this research the value of $\mathrm{KMO}$ is .747 and so, it is adequate for conducting factor analysis. 
Twenty-two variables were used for conducting a principle component factor analysis. The Table II of the appendix shows the communalities of the variables. From the table, the variance of extracted factors can be revealed. The solution using principle component factor analysis was conducted on the 22 variables related to happiness at workplace. The analysis drew out seven factor solutions that explained $63.4 \%$ of the variance.

The table II of the appendix shows that $95.8 \%$ of the variance in "My peers believe that I'm confident and productive employee" is accounted for by the extracted factors. While variables such as "I am happy with my efficiency of work" explains 59\% ,"I am valued by my supervisor" explains 51.1\% variance , "My supervisor believe that I can fulfill my responsibility efficiently" explains $53.3 \%$ and lastly "I've strong job security in this" variable explains $31.1 \%$ of variance. The table shows that variables such as, "My colleagues help me to solve work related problems" explains $69.7 \%$ of the variance was extracted as factor two while $59.5 \%$ of the variance in " My colleagues behave positively in my achievement" is explained and a lower communality of $35.6 \%$ of the variance in "I receive adequate opportunity to interact with other employees on a formal level" is understood.

For the dimension work family conciliation , $65.7 \%$ of the variance in "Regularly I get late to reach home after work as workload is so high that it takes two to three hour more at office after regular time" is accounted for by the extracted factor. While $64.5 \%$ of the variance in variable "The Company is flexible with respect to your family responsibilities" is accounted for by the factor extraction. A $68.5 \%$ variance in "I'm facing lack of open and frank discussion with management" is reported in comparison to the variable "I work under a lot of pressure" explains a lower communality of $47.5 \%$ variance. While $66.3 \%$ of the variance in "I get enough training to develop my competency" is reported. Table V below shows the total variance explained by each of the factor. The initial Eigen values showed that the first factor explained $22.52 \%$ of the variance, the second factor $10.46 \%$ of the variance, and a third factor $8.72 \%$ of the variance. The fourth $6.876 \%$, fifth $5.975 \%$, sixth factors $5.006 \%$ and seventh factor $4.844 \%$ of the variance explained respectively. Examining the varimax rotated factor solution, the most important factors for happiness at workplace account (My peers believe that I'm confident and productive employee and my colleagues help me to solve work related problems) $22.52 \%$ and $10.46 \%$. Thus the study reveals that the factor analysis of 22 variables loads on to seven factors.

Table VII. Total Variance Explained

\begin{tabular}{|l|c|c|c|}
\hline Name of the factor & \multicolumn{3}{|c|}{ Initial Eigen values } \\
\cline { 2 - 4 } & Total & $\%$ of Variance & Cumulative \% \\
\hline $\begin{array}{l}\text { 1. My peers believe that I'm confident and productive } \\
\text { employee }\end{array}$ & 4.735 & 21.522 & 21.522 \\
\hline $\begin{array}{l}\text { 2. My colleagues help me to solve work related } \\
\text { problems. }\end{array}$ & 2.300 & 10.456 & 31.978 \\
\hline $\begin{array}{l}\text { 3. I'm facing lack of open and frank discussion with } \\
\text { management }\end{array}$ & 1.920 & 8.726 & 40.705 \\
\hline 4. I get enough training to develop my competency. & 1.513 & 6.876 & 47.581 \\
\hline $\begin{array}{l}\text { 5. Regularly I get late to reach home after work as } \\
\text { workload is so high that it takes two to three hour } \\
\text { more at office after regular time. }\end{array}$ & 1.314 & 5.975 & 53.556 \\
\hline $\begin{array}{l}\text { 6. The company is flexible with respect to your family } \\
\text { responsibilities }\end{array}$ & 1.101 & 5.006 & 58.562 \\
\hline 7. I am happy with my efficiency of work & 1.066 & 4.844 & 63.406 \\
\hline
\end{tabular}

\section{IMPLICATION AND CONCLUSION}

The paper examined factors determining a happy worker in Bangladeshi private banks. To identify basic dimension of a happy worker, factor analysis was conducted on the variables using 
principle component technique which resulted from seven factors related to happiness at workplace. From the study it suggests that an employee is happy when he/she feels that their co workers perception towards their work and actions within the workplace is supportive. The study reveals that peer supportive behavior and interaction with coworkers plays an integral role in making an employee happy. A free and open discussion with management is also necessary for employees to be happy with their workplace. From the study employee suggests that they are happy with employers when training is given to develop their skills suggesting that when organizations invest in training for employees they feel important and hence feel happy regarding workplace. The study also reveals that working hour and work load and work-family balance are also important for an employee to be happy. A happy worker will most likely to be motivated and higher performer than an unhappy worker thus will reduce worker turnover. As echoed by Parker et al.'s (2003, p. 406):"psychological climate assessments should be part of interventions attempting to improve the quality of work life $(. .$.$) ", to reduce employee turnover and to improve$ motivation and performance. Lastly study suggests that workers feel happy when they realize that their work is effective and efficient and reach organizational goal. From the study, it is evident that workers or employees are happier when they directly see their contribution in betterment of the organization.

\section{Managerial Implication}

This study suggests the factors related to happy worker and as organizations, the focus must be given to those factors that make workers happy. Although monetary reward is important but the study reveals that workers are more concerned with the intrinsic nature of workplace. So a manager in order to get the best out of an employee need to ensure that workplace environment and factors like training and open and frank discussion must be also in place to make workers productive and happy thereby lowering turnover rate and increasing loyalty.

\section{Limitations and future research}

The research was conducted only on bank personnel located in the Dhaka City so the result may vary depending on the scope of the research area. There is scope of further research to see the difference of factors related to happiness in male and female and between various age groups.

\section{REFERENCES}

Azad, M. R., Khan, W., \& Ahmed, A. A. A. (2011). HR Practices in Banking Sector on Perceived Employee Performance: A Case of Bangladesh. Eastern University Journal, 3(3), 30-39. https://doi.org/10.5281/zenodo.4043334

Ahmed, M. (2015). The Role of Self-esteem and Optimism in Job Satisfaction among Teachers of Private Universities in Bangladesh. Asian Business Review, 1(2), 114-120. http://dx.doi.org/10.18034/abr.v1i2.322

Alam, M., \& Islam, M. (2012). Plan and Policies for Success in the Business World: A Conceptual Study. ABC Journal Of Advanced Research, 1(1), 60 - 69.

Alam, S. (2015). Factors Affecting Job Satisfaction, Motivation and Turnover Rate of Medical Promotion Officer (MPO) in Pharmaceutical Industry: A Study Based in Khulna City. Asian Business Review, 1(2), 126-131. doi:http://dx.doi.org/10.18034/abr.v1i2.324

Cohen, S.G. and Bailey, D.E., 1997. What makes teams work: Group effectiveness research from the shop floor to the executive suite. Journal of Management, 23(3), pp.239-290.

Comrey, A. L. (1992). A first course in factor analysis. Hillsdale, NJ: Lawrence Erlbaum

Crawford, C. and Krebs, D.L. eds., 2013. Handbook of evolutionary psychology: Ideas, issues, and applications. Psychology Press. 
D Robinson, S Perryman, S Hayday, The Drivers of Employee Engagement Report 408-ies- Published by: Institute for Employment studies Mantell Building, Falmer, Brighton BN19RF, UK.

Danna, K. and Griffin, R.W., 1999. Health and well-being in the workplace: A review and synthesis of the literature. Journal of Management, vol. 25 (3), pp. 357-384.

Furnham, A. and Christoforou, I., 2007. Personality traits, emotional intelligence, and multiple happiness. North American Journal of Psychology, 9(3), pp.439-462.

Hakim MA. Organizational Culture and Job Satisfaction in Bank: Perceptions and Reactions of Employees Global Disclosure of Economics and Business. 2015;4(2):167-180.

Haque, A., \& Ahmed, A. (2016). Striving for Work-Life Balance at Entry Level Jobs: Challenges to Develop Professionalism in Bangladesh. Asian Business Review, 6(2), 97-104. doi:http://dx.doi.org/10.18034/abr.v6i2.853

Hogg, J.C. and Hurd, H., 1995. Plasmodium yoelii nigeriensis: the effect of high and low intensity of infection upon the egg production and bloodmeal size of Anopheles stephensi during three gonotrophic cycles. Parasitology, 111(05), pp.555-562.

Islam, S. (2016). A New Method to Measure the Job Satisfaction Level of an Employee. Engineering International, 4(1), 19-24. doi:http://dx.doi.org/10.18034/ei.v4i1.826

Januwarsono. S(2015). Analytical of Factors Determinants of Happiness at Work Case Study on PT. PLN (Persero) Region Suluttenggo, Sulawesi, Indonesia. European Journal of Business and Management. $7(8)$

Khan M. Education and Health Status of Child Workers of Dhaka City Global Disclosure of Economics and Business. 2014; 3(2): 16-23.

Malhotra, N. K., (1996), Marketing Research: An Applied Orientation, 2nd Edition, New Jersey, Prentice Hall Inc.

McKenna, K.Y. and Bargh, J.A., 1999. Causes and consequences of social interaction on the Internet: A conceptual framework. Media Psychology, 1(3), pp.249-269.

McMahon, B., 2007, 'Organizational commitment, relationship commitment and their association with attachment style and locus of control', Thesis In Partial Fulfillment of the Requirements for the Degree Master of Science in Psychology, Georgia Institute of Technology.

Molla MI. Ensuring Job Satisfaction for Managing People at Work Global Disclosure of Economics and Business. 2015;4(2):155-166.

Nasima, M., \& Alam, N. (2015). Job Satisfaction among Female Fculties of Different Public and Private Universities in Bangladesh: A Comparative Analysis. ABC Journal Of Advanced Research, 4(1), 16 - 26.

Peter Warr, Work, Happiness, and Unhappiness Institute of Work Psychology, University of Sheffield, Mahwah: New Jersey: Lawrence Erlbaum Associates, Inc.

Rego, A. and e Cunha, M.P., 2008. Authentizotic climates and employee happiness: Pathways to individual performance? Journal of Business Research, vol. 61 (7), pp.739-752.

Rowden, R.W., 2002. The relationship between workplace learning and job satisfaction in the US small to midsize businesses. Human Resource Development Quarterly, 13(4), pp.407-425.

Stone, J. and Cooper, J., 2001. A self-standards model of cognitive dissonance. Journal of Experimental Social Psychology, vol. 37(3), pp.228-243.

Stones, Michael, et al. 2011. "Subjective well-being in later life: 20 years after the Butterworths Monograph Series on individual and population aging."Canadian Journal on Aging/La Revue Canadienne du vieillissement, pp 467-477.

Xiao-ran, L., Yan-ming, H., \& Cheng-cheng, W. (2015). Economic Analysis of the Pearl River Delta's "Labor Shortage". Asian Business Review, 4(2), 25-28. doi:http://dx.doi.org/10.18034/abr.v4i2.271 